\title{
ARTICLE
}

\section{A comparative study on Acorus calamus (Acoraceae) micro- propagation and selection of suitable population for cultiva- tion in Iran}

\author{
Abbas Gholipour ${ }^{1 *}$, Seyed Kamal Kazemitabar², Hamed Ramzanpour ${ }^{1}$ \\ ${ }^{1}$ Department of Biology, Faculty of Sciences, Payame Noor University (PNU), Tehran, Iran; \\ ${ }^{2}$ Department of Plant Breeding, Sari Agricultural and Natural Resources University (SANRU), Sari, Iran
}

\begin{abstract}
In addition to various medicinal properties, Acorus calamus (sweet flag) is used in health, food, and perfume industries. Since this species is a rare plant in Iran, its propagation and cultivation are of the great importance. The aim of this study was to investigate the effects of different plant growth regulators on micropropagation of this plant and to select the appropriate population. The root, the rhizome and the leaf explants of three populations (Arzefon, Pelesk, and Alandan) were cultured on MS medium supplemented with different concentrations of a-naphthalene acetic acid (NAA) and 6-benzylaminopurine (BAP) for callus induction and plant regeneration. The results showed that only rhizome explant resulted in direct plant regeneration. Among different treatments, the $1 \mathrm{mg} / \mathrm{l}$ treatment of BAP and NAA - with the highest mean number of regenerated plants $(3.75 \pm 0.85)$, the highest percentage of grown explants $(91.6 \%)$ and maximum average length of regenerated plants $(12.06 \pm 0.32 \mathrm{~cm})$ - was the best treatment for regeneration of sweet flag. The highest mean number of root $(6.6 \pm 0.1)$ was observed in Alandan population in $1 \mathrm{mg} / \mathrm{l}$ treatment of indole-3-butyric acid (IBA). According to the present study, Alandan population is suitable for cultivation purposes in Iran.

Acta Biol Szeged 65(1):29-34 (2021)
\end{abstract}

\author{
KEY WORDS \\ Acorus calamus \\ medicinal plants \\ micropropagation \\ sweet flag \\ tissue culture \\ ARTICLE INFORMATION
Submitted
15 November 2020.
Accepted
03 February 2021.
*Corresponding author
E-mail: a.gholipour@pnu.ac.ir
}

\section{Introduction}

Medicinal plants, as valuable natural resources, play an important role in the health and economy of any country. There are many reports about medicinal properties of Acorus calamus L. (sweet flag) in the traditional medicine of India, China and Iran. These medicinal properties include the treatment of appetite, digestive disorders, colic pain, fever, speech stammering, toothache, kidney and liver troubles, rheumatism, gout and rejuvenator of the brain and nervous system (Motley 1994; Imam et al. 2013; Mozaffarian 2013; Kumar et al. 2014). On the other hand, this plant is used in perfumery, health, and food industries (Motley 1994; Kumar et al. 2014).

A. calamus has recently been rediscovered in Iran after about 50 years from Mazandaran province (Gholipour and Sonboli 2013). It is a rhizomatous perennial semi-aquatic plant from the family Acoraceae which mainly grows around the ponds in Iran. According to the available information, sweet flag has been distributed in three localities with very restricted distribution in Mazandaran (North of Iran) and is considered as a rare plant in Iran (Gholipour and Sonboli 2013). At present, the raw materials of sweet flag for medicinal and other uses are provided from natural habitats. For this reason, harvesting this plant will probably lead to the extinction of the species in Iran. Due to the many usages of $A$. calamus and high demand, domestication and cultivation of this plant in Iran is necessary. Sweet flag often has vegetative reproduction through rhizome, and no seed is produced in the wild population of Iran. On the other hand, since this plant does not produce seed, the preparation of seedlings is one of the main problems in the cultivation of this plant. At present, in countries where this plant is cultivated, the rhizomes of the previous year's plant are kept under soil until the growing season and then used to prepare seedlings (Lokesh 2004; Imam et al. 2013). Keeping the living rhizome underground for about 4 months is one of the major problems in cultivating of this plant.

Plant tissue culture is a suitable technique for solving problems in the field of cultivation, exploitation and conservation of medicinal and ornamental plants (Mohamed et al. 2007; Bhagat 2011; Imam et al. 2013; Chandana et al. 2018; Fallah et al. 2019). Some studies have successfully propagated $A$. calamus through tissue culture technique, but there is some difference between them in the proper combination of the plant growth regulators 
Gholipour et al.

Table 1. Localities and vouchers information of the studied populations of $A$. calamus.

\begin{tabular}{lll}
\hline No. & Locality/Time/Height/Collector & Voucher number \\
\hline 1 & Iran, Mazandaran, Sari, Arzefon village, Malepeshte Ab-bandan / 03. 11. 2017 / 331 m / Gholipour A & SPNH-5919 \\
2 & Iran, Mazandaran, Sari, Shahid Rajaii dam road, Pelesk village, Ab-bandane Pelesk / 05. 07. 2018 / 660 m / Gholipour A & SPNH-5991 \\
3 & Iran, Mazandaran, Sari to Kiasar road, before Kiasar, Alandan, Ab-bandane Alandan / 09. 06. 2018 / 1350 m / Gholipour A & SPNH-5997 \\
\hline
\end{tabular}

(Hettiarachchi et al. 1997; Rani et al. 2000; Anu et al. 2001; Ahmed et al. 2007; Altaf et al. 2010; Sandhyarani et al. 2011; Devi et al. 2012; Verma and Singh 2012; Dixit et al. 2014; Babar et al. 2020). It seems that one of the reasons for these differences is due to the geographical distribution of the studied populations. Based on a review of scientific literature, no information is available on the micropropagation of $A$. calamus using native plants of Iran. This study was conducted to prepare a suitable protocol for micropropagation of this plant using tissue culture technique on plant samples of three populations and, selecting the appropriate population for large-scale cultivation and conservation purposes in Iran.

\section{Materials and Methods}

\section{Plant materials and sterilization}

Fresh plant materials (rhizomes, roots, and leaves) of three populations of A. calamus were collected from Arzefon, Pelesk, and Alandan (Sari- Mazandaran- North of Iran) ponds (Table 1). Herbarium vouchers are deposited in Sari Payame Noor University Herbarium (SPNH). The samples were cleaned and thoroughly washed in running tap water. The $0.5-1.5 \mathrm{~cm}$ segments of root, rhizome, and leaf were cut. All samples were washed in liquid detergent for $5 \mathrm{~min}$. The explants were then washed several times in tap water, followed by washing with distilled water to remove detergent traces. Samples were sterilized with ethanol 70\% for $3 \mathrm{~min}$. Due to the fungal infection of rhizomes of this plant, we treated the rhizome explants in mercuric chloride solution $\left(\mathrm{HgCl}_{2}\right) 0.1 \%(\mathrm{w} / \mathrm{v})$ for 15 min. Again, the explants were thoroughly washed several times in autoclaved distilled water.

\section{Establishment of culture}

In callus induction experiment, root, leaf and rhizome explants were cultured in MS medium supplemented with $0.5,1$ and $2 \mathrm{mg} / 1 \alpha$-naphthalene acetic acid (NAA). In direct plant regeneration experiment, the explants were incubated on MS medium supplemented with four combined treatments of 1-2 mg/l 6-benzylaminopurine (BAP) and $0.5-1 \mathrm{mg} / 1 \alpha$-naphthalene acetic acid (NAA) (Table 2). In both experiments; callus induction and direct plant regeneration, control samples were incubated on MS medium without any plant growth regulator. The experiments were performed in a completely randomized block design with 3 replications, and 3-4 explants were incubated in each replication. The cultures were incubated in a growth chamber at $25 \pm 2{ }^{\circ} \mathrm{C}$ temperature, 16 hours' photoperiod, and $75-85 \%$ humidity for 15 days. The time it takes for bud break of each explant, the num-

Table 2. The effect of different plant growth regulators treatments on plant regeneration of rhizome explants in three Iranian populations of $A$. calamus (15 days after cultures). Values are mean \pm standard error; all values are averaged except growing explant percentage.

\begin{tabular}{|c|c|c|c|c|c|c|c|c|c|c|c|c|}
\hline \multirow[b]{2}{*}{ Populations } & \multicolumn{3}{|c|}{$\begin{array}{l}\text { Mean days for } \\
\text { bud break }\end{array}$} & \multicolumn{3}{|c|}{$\begin{array}{l}\text { Grown explants } \\
\text { percentage }(\%)\end{array}$} & \multicolumn{3}{|c|}{$\begin{array}{l}\text { Mean number of } \\
\text { regenerated plantlets }\end{array}$} & \multicolumn{3}{|c|}{$\begin{array}{l}\text { Average length of } \\
\text { plantlets }(\mathrm{cm})\end{array}$} \\
\hline & Arzefon & Pelesk & Alandan & Arzefon & Pelesk & Alandan & Arzefon & Pelesk & Alandan & Arzefon & Pelesk & Alandan \\
\hline \multicolumn{13}{|l|}{ Treatments } \\
\hline Control & $\begin{array}{l}15 \pm \\
0.35\end{array}$ & $\begin{array}{l}7 \pm \\
0.175\end{array}$ & 13 & 16.6 & 16.6 & 8.3 & 0.5 & 0.5 & 0.25 & $\begin{array}{l}1 \pm \\
0.062\end{array}$ & $\begin{array}{l}2.5 \pm \\
0.125\end{array}$ & 1.5 \\
\hline $\begin{array}{l}\text { BAP } 1 \mathrm{mg} / \mathrm{l}+ \\
\text { NAA } 0.5 \mathrm{mg} / \mathrm{l}\end{array}$ & $\begin{array}{l}2.5 \pm \\
0.01\end{array}$ & $\begin{array}{l}2.87 \pm \\
0.01\end{array}$ & $\begin{array}{l}4.25 \pm \\
0.04\end{array}$ & 58.3 & 66.6 & 66.6 & $\begin{array}{l}1.75 \pm \\
0.25\end{array}$ & 2 & $\begin{array}{l}3 \pm \\
0.57\end{array}$ & $\begin{array}{l}3.62 \pm \\
0.31\end{array}$ & $\begin{array}{l}4.81 \pm \\
0.18\end{array}$ & $\begin{array}{l}6.64 \pm \\
1\end{array}$ \\
\hline $\begin{array}{l}\text { BAP } 1 \mathrm{mg} / \mathrm{l}+ \\
\text { NAA } 1 \mathrm{mg} / \mathrm{l}\end{array}$ & $\begin{array}{l}3.5 \pm \\
0.016\end{array}$ & $\begin{array}{l}3 \pm \\
0.02\end{array}$ & $\begin{array}{l}3.06 \pm \\
0.01\end{array}$ & 75 & 58.3 & 91.6 & $\begin{array}{l}2.25 \pm \\
0.25\end{array}$ & $\begin{array}{l}1.75 \pm \\
0.25\end{array}$ & $\begin{array}{l}3.75 \pm \\
0.85\end{array}$ & $\begin{array}{l}4.95 \pm \\
0.21\end{array}$ & $\begin{array}{l}3.87 \pm \\
0.23\end{array}$ & $\begin{array}{l}12.06 \pm \\
0.32\end{array}$ \\
\hline $\begin{array}{l}\text { BAP } 2 \mathrm{mg} / \mathrm{l}+ \\
\text { NAA } 0.5 \mathrm{mg} / \mathrm{l}\end{array}$ & $\begin{array}{l}3.25 \pm \\
0.02\end{array}$ & $\begin{array}{l}5 \pm \\
0.026\end{array}$ & $\begin{array}{l}7.6 \pm \\
0.44\end{array}$ & 66.6 & 83.3 & 25 & $\begin{array}{l}2 \pm \\
0.40\end{array}$ & $\begin{array}{l}2.5 \pm \\
0.28\end{array}$ & $\begin{array}{l}1.5 \pm \\
0.95\end{array}$ & $0.56 \pm 0.1$ & $\begin{array}{l}3.12 \pm \\
0.46\end{array}$ & $\begin{array}{l}11.5 \pm \\
0.03\end{array}$ \\
\hline $\begin{array}{l}\text { BAP } 2 \mathrm{mg} / \mathrm{l}+ \\
\text { NAA } 1 \mathrm{mg} / \mathrm{l}\end{array}$ & $\begin{array}{l}2.75 \pm \\
0.007\end{array}$ & $\begin{array}{l}3.5 \pm \\
0.036\end{array}$ & $\begin{array}{l}4 \pm \\
0.023\end{array}$ & 66.6 & 75 & 83.3 & $\begin{array}{l}2 \pm \\
0.40\end{array}$ & $\begin{array}{l}2.25 \pm \\
0.25\end{array}$ & $\begin{array}{l}3.5 \pm \\
0.28\end{array}$ & $\begin{array}{l}0.31 \pm \\
0.06\end{array}$ & $\begin{array}{l}3.31 \pm \\
0.23\end{array}$ & $\begin{array}{l}8.25 \pm \\
0.32\end{array}$ \\
\hline
\end{tabular}


Table 3. The effects of IBA at different concentrations on the plantlets root production of three Iranian populations of $A$. calamus (21 days after cultures). Values are mean \pm standard error.

\begin{tabular}{|c|c|c|c|c|c|c|c|c|c|}
\hline \multirow[b]{2}{*}{ Populations } & \multicolumn{3}{|c|}{ Mean number of roots } & \multicolumn{3}{|c|}{ Root formation (\%) } & \multicolumn{3}{|c|}{ Average length of roots $(\mathrm{cm})$} \\
\hline & Arzefon & Pelesk & Alandan & Arzefon & Pelesk & Alandan & Arzefon & Pelesk & Alandan \\
\hline \multicolumn{10}{|l|}{ Treatments } \\
\hline IBA $0.5 \mathrm{mg} / \mathrm{l}$ & $1.6 \pm 0.26$ & $3 \pm 0.09$ & $5 \pm 0.09$ & 33.3 & 100 & 100 & $1.25 \pm 0.02$ & $3 \pm 0.06$ & $2.5 \pm 0.06$ \\
\hline IBA 1 mg/l & $2 \pm 0.15$ & $2.3 \pm 0.05$ & $6.6 \pm 0.1$ & 66.6 & 100 & 100 & $0.5 \pm 0.01$ & $1.75 \pm 0.06$ & $3.75 \pm 0.04$ \\
\hline
\end{tabular}

ber of grown explants, the number of plants regenerated per culture, and the length of regenerated plantlets were recorded after 15 days of culture.

\section{Root induction}

The regenerated plantlets (about 5-7 cm) were aseptically transferred to rooting medium containing MS medium supplemented with 0.5 and $1 \mathrm{mg} / 1$ indole-3-butyric acid (IBA). The cultures were incubated in the growth chamber under the same conditions as the plant regeneration experiment. After 21 days, the number and the length of the initiated roots were measured per culture.

\section{Evaluation of Biomass performance}

The weight of 12 well-developed rooted plantlets from each population were measured, then planted in pots containing an autoclaved mixture of soil and sand (3:1). The pots, after being acclimatized were transferred to the greenhouse, and maintained in the same condition. After 30 days, all plantlets were removed from the pots, washed thoroughly with tap water and the weight of each plantlet in each population was measured. Finally, all plantlets were planted in the field of Sari Payame Noor University.

\section{Data analysis}

In direct plant regeneration experiment, mean time of bud break, the percentage of grown explants, mean number and mean length of regenerated plantlets in each treatment were calculated in cultures of each population. In rooting induction culture, mean number of initiated roots, the percentage of root formation and mean length of root in each treatment were calculated for plant samples of each population. The plantlets survival rate and mean total final plantlets weight per population were calculated for viability and biomass yield evaluation. Analysis of variance (ANOVA) and Duncan multiple range test were performed at the 5\% level of significance using SPSS ver. 19 software (IBM 2010) for data analysis of plant regeneration, root induction and biomass performance.

\section{RESULTS}

\section{Callus induction and plant regeneration}

Callus induction and indirect plant regeneration of sweet flag were not successful in leaf and root explants. Plant regeneration occurred only in the rhizome explants, while no callus was produced in its different treatments. The results of direct plant regeneration treatments of three Iranian populations of $A$. calamus samples are presented in Table 2. Regeneration of plantlets occurred in all treatments, but various responses to different concentrations of plant growth regulators were observed in explants of three populations. The lowest mean time of explant bud break ( $2.5 \pm 0.01$ days) was found in $1 \mathrm{mg} / 1 \mathrm{BAP}$ in combination with $0.5 \mathrm{mg} / 1$ NAA treatment of Arzefon population, while the highest one (15 \pm 0.35 days) was observed in control treatment of this population. Based on the analysis of variance (ANOVA), there was no significant difference $(\mathrm{Sig}=0.439)$ between the mean time of explant bud break in different treatments of three studied populations. As a result, different combinations of plant growth regulators have relatively similar effects on explant bud breaking time for plant regeneration. In all treatments, except control treatments and $2 \mathrm{mg} / 1 \mathrm{BAP}$ in combination with $0.5 \mathrm{mg} / 1 \mathrm{NAA}$ treatment of Alandan population, the first explant began to grow after 2 days.

The maximum percentage of grown explant (91.6\%) was observed in $1 \mathrm{mg} / 1 \mathrm{BAP}$ combined with $1 \mathrm{mgl}^{-1} \mathrm{NAA}$ treatment of Alandan population and the least one (8.3\%) was observed in control treatment of this population. Analysis of variance showed that there was a significant difference at $5 \%$ level in the grown explant percentage between populations $(\mathrm{Sig}=0.011)$. Duncan's multiple range tests showed that there was a significant difference $(\mathrm{Sig}=0.012)$ between Alandan and Pelesk populations plant samples in terms of grown explants percentage in $1 \mathrm{mg} / 1 \mathrm{BAP}$ in combination with $1 \mathrm{mg} / \mathrm{l} \mathrm{NAA}$ treatment and $2 \mathrm{mg} / 1 \mathrm{BAP}$ combined with $0.5 \mathrm{mg} / 1 \mathrm{NAA}$ treatment.

The highest mean number of the regenerated plantlet $(3.75 \pm 0.85)$ was found in $1 \mathrm{mg} / 1 \mathrm{BAP}$ in combination with $1 \mathrm{mg} / 1 \mathrm{NAA}$ treatment of Alandan population plant samples and the least one (0.5) was observed in control treatment of this population (Fig. 1A). In this investiga- 


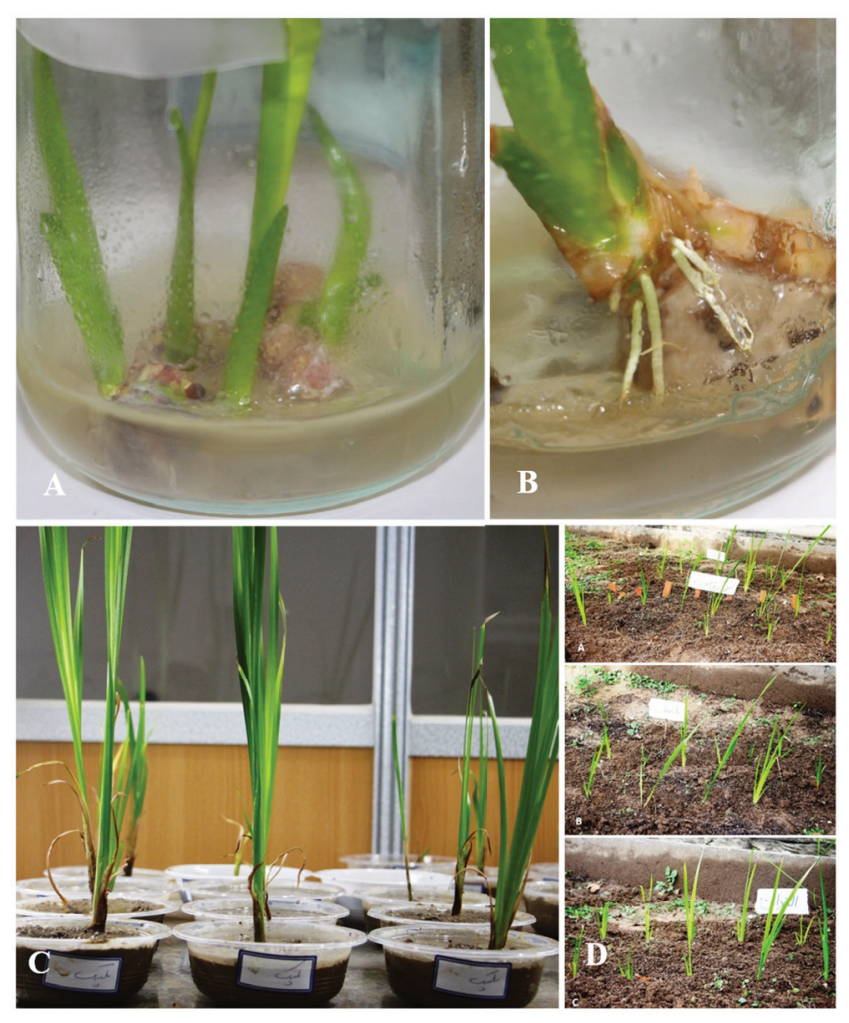

Figure 1. Micropropagation of plant samples of Iranian populations of A. calamus from rhizome explants. A: Regenerated plantlets of Alandan population from $1 \mathrm{mg} / \mathrm{l} \mathrm{BAP}+1 \mathrm{mg} / \mathrm{I}$ NAA treatment. B: Root induction in $1 \mathrm{mg} / \mathrm{I}$ IBA treatment of Alandan population plantlet. C: Plantlets of Pelesk population in greenhouse. D: Developed regenerated plantlets of Arzefon, Pelesk and Alandan populations planted in the field.

tion, the maximum number of regenerated plantlets (15) was found in $1 \mathrm{mg} / \mathrm{lBAP}$ and NAA treatment of Alandan population culture, and the maximum number of plantlets per explant (4 plantlets) was produced in an explant of Alandan population. Analysis of variance indicated that there was a significant difference at $5 \%$ level for the mean number of the regenerated plantlets between different populations $(\mathrm{Sig}=0.016)$. Duncan multiple range test showed that there was a significant difference (Sig $=0.017$ ) between Alandan and Pelesk, and Alandan and Arzefon populations cultures $(\mathrm{Sig}=0.020)$ in terms of mean number of regenerated plantlets.
The highest average length of regenerated plantlets $(12.06 \pm 0.32 \mathrm{~cm})$ was found in $1 \mathrm{mg} / 1 \mathrm{BAP}$ in combination with $1 \mathrm{mg} / 1 \mathrm{NAA}$ treatment of Alandan population after 15 days. There was a significant difference in the mean length of the regenerated plantlets between Alandan with Arzefon and Pelesk populations ( $\mathrm{Sig}=0.001)$. In contrast, no significant difference was observed between Arzefon and Pelesk populations plant samples $(\mathrm{Sig}=0.40)$ in 1 $\mathrm{mg} / \mathrm{l} \mathrm{BAP}$ in combination with $1 \mathrm{mg} / \mathrm{l} \mathrm{NAA}$ and $1 \mathrm{mg} / 1$ BAP combined with $0.5 \mathrm{mg} / 1 \mathrm{NAA}$ treatments.

\section{Rooting of regenerated plants}

The effects of different concentrations of IBA on root induction of the studied populations were presented in Table 3. In the control medium, no roots were developed. The percentage of root formation was recorded 100\% in two treatments of Alandan and Pelesk population plantlets, while the lowest one (33.3\%) was observed in $0.5 \mathrm{mg} / 1$ IBA treatment of Arzefon population plantlets. The maximum mean number of the developed root $(6.6$ $\pm 0.1)$ and the highest mean length of root $(3.75 \pm 0.04$ $\mathrm{cm}$ ) were observed in $1 \mathrm{mg} / 1$ IBA treatment of Alandan population plantlets (Fig. 1B). Based on the analysis of variance, there was a significant difference in terms of the mean number of produced roots $(\mathrm{Sig}=0.005)$ and the mean length of roots $(\mathrm{Sig}=0.01)$ between three populations plantlets. As a result, different growth regulator treatments had different effects on root production in regenerated plantlets of different populations.

\section{Viability rate and biomass performance}

All rooted plantlets of Arzefon and Pelesk populations grew in the greenhouse, while the survival rate was $83 \%$ in Alandan population plantlets (Table 4). Analysis of variance on biomass yield of the three studied populations showed a significant difference between the populations $(\mathrm{Sig}=0.000)$. Duncan's multiple range tests showed that there was a significant difference (Sig $=0.017$ ) between Pelesk with Alandan and Arzefon populations, and there was no significant difference between Arzefon and Alandan populations $(\mathrm{Sig}=0.061)$. As a result, the plantlets of Pelesk population, with about $400 \%$ increase in biomass after 30 days, showed better performance compared to other populations plantlets (Fig. 1C).

Table 4. Variation of viability and biomass production of plantlets in three Iranian populations of $A$. calamus (after 30 days).

\begin{tabular}{lllll}
\hline Populations & Viability (\%) & Primary total weight (g) & Final total weight (g) & Average final total weight (g) \\
\hline Arzefon & 100 & 22.35 & 55.25 & $4.6 \pm 0.01 \mathrm{a}$ \\
Pelesk & 100 & 22.5 & 102.3 & $8.5 \pm 0.13 \mathrm{~b}$ \\
Alandan & 83.3 & 22.30 & 52.5 & $4.37 \pm 0.19 \mathrm{a}$ \\
\hline
\end{tabular}




\section{Discussion}

To achieve an effective micropropagation protocol and determine the appropriate population, the tissue culture of plant samples of three populations of $A$. calamus was performed for the first time in Iran. As other studies have reported (Rani et al. 2000; Ahmed et al. 2007; Sandhyarani et al. 2011; Verma and Singh 2012; Dixit et al. 2014), fungal contamination of the culture medium was the most important problem in this study. In accordance with some studies, callus formation and indirect plant regeneration using rhizome, leaf and root explants at different concentrations of plant growth regulators were not successful (Rani et al. 2000; Ahmed et al. 2007; Sandhyarani et al. 2011; Verma and Singh 2012). Dixit et al. (2014) reported regeneration of this plant using leaf explant in combined treatment of BA and NAA (2.5 $\mathrm{mg} / 1+1 \mathrm{mg} / \mathrm{l})$. According to this study, only the lowest basal part of the leaf was effective in plant regeneration and the rest part of leaf was not useful. It seems that the small buds at the base of the leaf were probably effective in regenerating the plant.

The results of the present research, like previous studies, showed that rhizome is suitable organ for micropropagation of sweet flag (Hettiarachchi et al. 1997; Rani et al. 2000; Ahmed et al. 2007; Sandhyarani et al. 2011; Verma and Singh, 2012; Dixit et al. 2014). Various plant growth regulators, including cytokinins (Kin and BAP) and auxins (IBA, IAA, and NAA), have been used alone or in combination for callus induction, plant regeneration, and root formation in this plant. The results of the present study, as in other studies, showed that BAP (among the cytokinins) and IBA and NAA (among the auxins) are the most suitable plant growth regulators for A. calamus micropropagation (Rani et al. 2000; Ahmed et al. 2007; Sandhyarani et al. 2011; Verma and Singh, 2012; Dixit et al. 2014).

$1 \mathrm{mg} / \mathrm{l}$ BAP and NAA treatment is the most suitable treatment in comparison with other treatments, in direct plant regeneration of Iranian populations of sweet flag. In the study of Hettiarachchi et al. (1997), the combined treatment of $0.5 \mathrm{mg} / 1 \mathrm{BAP}$ with $0.2 \mathrm{mg} / 1 \mathrm{NAA}$ showed the best performance in plant regeneration. On the other hand, the highest number of regenerated plants was found in combined treatment of BAP and NAA (Anu et al. 2001). The maximum number of regenerated plants was observed in combined treatment of BAP and NAA (2 $\mathrm{mg} / \mathrm{l}$ and $0.5 \mathrm{mg} / \mathrm{l}$ ) (Ahmed et al. 2007; Verma and Singh 2012). The maximum number of proliferated shoots was observed in MS medium supplemented with $4 \mathrm{mg} / \mathrm{l}$ BAP and $0.5 \mathrm{mg} / \mathrm{l}$ IAA (Rani et al. 2000). The results of the present study are in accordance with other studies in terms of the type of plant growth regulators (BAP and
NAA), but there are differences in the concentration of plant growth regulators (Hettiarachchi et al. 1997; Anu et al. 2001; Ahmed et al. 2007; Verma and Singh, 2012). Since most of the mentioned studies have been done on plant samples of Indian populations, one of the possible reasons for this discrepancy is related to the geographical distribution differences of the studied populations.

The regenerated plantlets of Arzefon, Pelesk, and Alandan populations showed different responses in rooting treatments. The plantlets of Alandan population, with the highest mean number $(6.6 \pm 0.1)$ and average length of $\operatorname{root}(3.75 \pm 0.04 \mathrm{~cm})$ in $1 \mathrm{mg} / 1$ IBA treatment, showed the best performance among root induction treatments. The results of this study are completely in accordance with the studies of Ahmed et al. (2007), Altaf et al. (2010) and Verma and Singh (2012) in terms of type and concentration of plant growth regulators. The maximum number of the roots was observed in $9.8 \mu \mathrm{M}$ concentration of IBA (Anu et al. 2001), and $2 \mathrm{mg} / \mathrm{l}$ IBA (Sandhyarani et al. 2011). Based on the results of this study, Alandan population plantlets showed better response in root induction experiment than other populations.

The regenerated plantlets of Iranian populations showed significant viability in the greenhouse. Plants of Arzefon and Pelesk populations had 100\% viability, whereas plant samples of Alandan showed 83\% viability. On the other hand, all the plantlets transferred to the field also survived until the end of growing season (Fig. 1D). The rooted plants showed about $90-95 \%$ viability in the greenhouse (Rani et al. 2000; Anu et al. 2001; Altaf et al. 2010), while Verma and Singh (2012) reported that about $75 \%$ of the plants survived in the field. In terms of survival rate of the regenerated plantlets in greenhouse and field, the results of this study are in accordance with some of the findings. According to the results of this study, plants of Alandan population of $A$. calamus are recommended for micpropagation and cultivation in Iran.

\section{Conclusion}

Due to the increasing demand for A. calamus products, it is necessary that this rare plant be propagated and cultivated in Iran. Because of vegetative reproduction, and no seed production in the Iranian wild populations of the species, the providing of plantlets for planting in suitable season is a great problem in the cultivation of this plant. This study presented an efficient protocol for sweet flag micropropagation to providing large-scale plantlets without any time limitation, and suggested plants of Alandan population of A. calamus as suitable accession for cultivation in Iran. This protocol can also be used for the conservation purposes of this plant. 


\section{Acknowledgments}

The authors are thankful to Azam Ebrahimi, Maryam Ramrodi, and Maryam Nikzad for their cooperation in laboratory works. The authors would like to thank Ms. Zahra Sadeghi for English language editing of the manuscript. This study was funded by Iran National Science Foundation (INSF) and Payame Noor University (grant number 96003519).

\section{REFERENCES}

Ahmed MB, Ahmed S, Salahin M, Sultana M, Khatun M, Razvy MA, Hannan MM, Islam R, Hossain MM (2007) Standardization of a suitable protocol for in vitro clonal propagation of Acorus calamus L. an important medicinal plant in Bangladesh. Am-Euras J Sci Res 2(2):136-140.

Altaf A, Shashidhara S, Rajshekharan PE, Harees KV, Honnesh NH (2010) In vitro regeneration of Acorus calamus - an important medicinal plant. J Curr Pharma Res 2(1):36-39.

Anu A, Babu KN, John CZ, Peter KV (2001) In vitro clonal multiplication of Acorus calamus. J Plant Biochem Biotechnol 10:53-55.

Babar PS, Deshmukh AV, Salunkhe SS, Chavan JJ (2020) Micropropagation, polyphenol content and biological properties of Sweet Flag (Acorus calamus): a potent medicinal and aromatic herb. Vegetos 33:296-303.

Bhagat N (2011) Conservation of endangered medicinal plant (Acorus calamus) through plant tissue culture. J Pharmacogn 2(1):21-24.

Chandana BC, Kumari Nagaveni HC, Lakshmana D, Shashikala SK, Heena MS (2018) Role of plant tissue culture in micropropagation, secondary metabolites production and conservation of some endangered medicinal crops. J Pharmacogn Phytochem 7(3S):246-251.

Devi NS, Kishor R, Sharma GJ (2012) Microrhizome induction in Acorus calamus Linn. - An important medicinal and aromatic plant. Hortic Environ Biotechnol 53:410-414.

Dixit V, Purshottam DK, Agnihotri P, Husain T, Misra P (2014) A highly efficient shoot organogenesis system of Acorus calamus - a threatened medicinal plant of Indian Himalaya. Experiment J 21(1):1453-1461.
Fallah M, Farzaneh M, Yousefzadi M, Ghorbanpour M, Mirjalili MH (2019) In vitro mass propagation and conservation of a rare medicinal plant, Zhumeria majdae Rech. f \& Wendelbo (Lamiaceae). Biocatal Agric Biotechnol 17:318-325.

Gholipour A, Sonboli A (2013) Rediscovery of Acorus calamus (Acoraceae) in Iran. Taxonomy and Biosystematics 5(15):113-116. [In Persian]

Hettiarachchi A, Fernando KKS, Jayasuriya AHM (1997) In vitro propagation of Wakada (Acorus calamus). J Natn Sci Coun Sri Lanka 25(3):151-157.

IBM (2010) IBM SPSS Statistics for Windows, Version 19.0. IBM, New York, USA.

Imam H, Riaz Z, Azhar M, Sofi G, Hussain A (2013) Sweet flag (Acorus calamus Linn.): An incredible medicinal herb. Int J Green Pharm 7:288-296.

Kumar A, Kumar P, Kumar V, Kumar M (2014) Traditional uses of wetland medicinal plant Acorus calamus: review and perspectives. Int J Referred Online Res 2(5):37-67.

Lokesh GB (2004) Sweet flag (Acorus calamus) cultivation and economics aspects. Nat Prod Rad 3(1):19-20.

Mohammed E-S E-M, Dewir YH, Singh N (2007) Indirect shoot organogenesis and plantlets regeneration from stem of ornamental Dieffenbachia maculata cv. Marianna. Acta Biol Szeged 51(2):113-116.

Motley TJ (1994) The ethnobotany of sweet flag, Acorus calamus (Araceae). Econ Bot 48:397-412.

Mozaffarian V (2013) Identification of Medicinal and Aromatic Plants of Iran. Farhange-Moaser Publication, Tehran. p.42-43. [In Persian]

Rani AS, Subhadra VV, Reddy VD (2000) In vitro propagation of Acorus calamus Linn. - a medicinal plant. Indian J Exp Biol 38:730-732.

Sandhyarani N, Kishor R, Sharma GJ (2011) Clonal propagation of triploid Acorus calamus Linn. using dual-phase culture system. J Crop Sci Biotechnol 14(3):213-217.

Verma S, Singh N (2012) In vitro Mass multiplication of Acorus calamus L. - an endangered medicinal plant. Am Eurasian J Agric Environ Sci 12(11):1514-1521. 